\title{
The Effectiveness of Chlorpromazine to Decrease the Level of Tumor Necrosis Factor-Alpha Serum in Schizophrenic Patients with Coronavirus Disease 2019
}

\author{
Andi Jayalangkara Tanra* ${ }^{1}$ (i) Ahmad Andi Sameggu ${ }^{1}$, Rinvil Renaldi ${ }^{1}$, Burhanuddin Bahar $^{2}$, Saidah Syamsuddin ${ }^{1}$ (D), Muhammad \\ Ilyas $^{3}$, Sonny T. Lisal ${ }^{1}$
}

${ }^{1}$ Department of Psychiatry, Faculty of Medicine, Hasanuddin University, Makassar, South Sulawesi, Indonesia; ${ }^{2}$ Department of Public Health, Faculty of Public Health, Hasanuddin University, Makassar, South Sulawesi, Indonesia; ${ }^{3}$ Department of Pulmonology, Faculty of Medicine, Hasanuddin University, Makassar, South Sulawesi, Indonesia

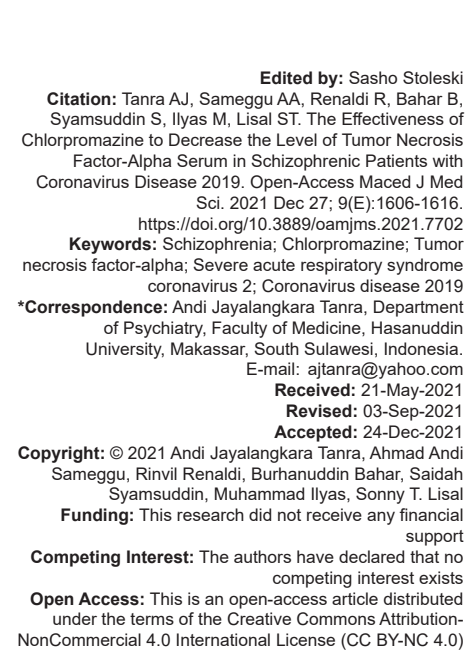

\section{Introduction}

A case of pneumonia with no known cause was first reported in Wuhan, Hubei Province, China, in December 2019. The disease is spreading rapidly globally and the World Health Organization has declared the disease a coronavirus disease 2019 (COVID-19) caused by a virus. Severe acute respiratory syndrome coronavirus-2 (SARS-CoV-2) declared a global pandemic in March 2020 [1]. The COVID-19 pandemic has created an unprecedented crisis of infectious diseases in the world. As of March 8, 2021, globally, there have been 121 million confirmed cases of COVID-19 with 2.7 million deaths. Meanwhile, according to the Ministry of Health, it reported 1,386,566 confirmed cases of COVID-19 with 38,547 deaths so that research continues to find an effective anti-viral to treat COVID-19 so that it ends soon.

\begin{abstract}
BACKGROUND: The ongoing coronavirus disease 2019 (COVID-19) pandemic caused by the severe acute respiratory Dirus-2. The COVID-19 pandemic has also had an impact on mental health, including those with to examine the effectiveness of chlorpromazine on serum TNF-values in schizophrenic

METHODS: This research is a nested case-control study. The study was conducted on schizophrenic patients with mild and asymptomatic cases of COVID-19 at Dadi Mental Hospital with a sample of 40 patients compared to 42 Serum tumor necrosis factor-alpha (TNF- $\alpha$ ) concentrations were measured by enzyme-linked immunosorbent assays RESULTS: The comparison of baseline TNF-serum levels that increased in the schizophrenic group with COVID-19 was $9.33 \mathrm{pg} / \mathrm{ml}$ higher, compared to the schizophrenic group without COVID-19. The decrease in TNF-levels in the

CONCLUSION:The serumTNF-Va TNF- values in schizophrenic patients with COVID-19. The administration of chlorpromazine and antipsychotic in therapeutic doses reduced the total PANSS and CGI-SCH values.
\end{abstract} impact on mental health. Psychological and behavioral symptoms that often appear in the form of anxiety, sleep disturbances, frustration, feelings of insecurity, irritability, avoiding health services for fear of being considered sick with COVID-19, and risky behaviors such as increased alcohol consumption, substance abuse, smoking, changes in work patterns, isolation, and increasing conflict in the family environment [2]. Severe mental disorders such as schizophrenia (SCH) are also affected by the COVID-19 pandemic. In a study at New York University, there were 75 patients with $\mathrm{SCH}$ spectrum disorder who were confirmed positive for COVID-19 and 20 of them died. This makes $\mathrm{SCH}$ a high-risk factor for mortality in COVID-19 patients [3]. A study at Greater Paris University, 55 patients with psychotic symptoms with COVID-19 in the intensive care unit (ICU) received chlorpromazine at an average dose of $70.8 \mathrm{mg} /$ day [4]. 
Based on clinical observations, as many as 80 patients with mental disorders at the Dadi Makassar Special Hospital were positive for COVID-19 in December 2020 and the majority of patients had no symptoms and some mild symptoms. According to the latest data in February 2021, there were again 51 positive COVID-19 patients who came from different wards from December 2020 case, and all patients did not experience any clinical symptoms of COVID-19. The patient received typical and atypical anti-psychotic therapy including haloperidol, chlorpromazine, risperidone, and clozapine. Appropriate intervention is needed in mental disorders with COVID-19 to prevent high mortality.

Chlorpromazine is a dimethylamine derivative of phenothiazine which is used in the treatment of both acute and chronic psychosis [5]. Chlorpromazine is believed to have potential as an anti-viral and antiinflammatory which can be beneficial in COVID-19 patients [6]. In particular, in vitro studies [7], [8], it was found that chlorpromazine decreased the replication of the Middle East respiratory syndrome coronavirus (MERS-CoV) and SARS-CoV-1 viruses which became the basis for the FDA approved chlorpromazine as a MERS-CoV therapy. The anti-viral mechanism may be through the dynamin inhibitor clathrin-mediated endocytosis [9].

Chlorpromazine has a role in the dysregulation of pro-inflammatory agents in $\mathrm{SCH}$, in accordance with the theory of neuroinflammation in SCH. Pro-inflammatory agents involved in $\mathrm{SCH}$ include interleukin (IL)-1 $\beta$, IL-2, IL-6, and tumor necrosis factor- $\alpha$ (TNF- $\alpha)$ [10]. In vitro studies on mouse models [11], chlorpromazine administration was associated with decreasing proinflammatory cytokines IL-2, IL-4, interferon- $\alpha$, TNF- $\alpha$, and stimulating granulocyte macrophage colonies as, well as increasing anti-inflammatory cytokine IL-10, specifically on in vitro studies [12]. Chlorpromazine dose of $300 \mathrm{mg} /$ day, TNF- $\alpha$ was found to be more significant at concentrations multiples of 0.25 times ( $75 \mathrm{mg} /$ day) and $2 \times(600 \mathrm{mg} / \mathrm{day})$.

Several studies have explained the association of TNF- $\alpha$ with SCH. Lee's study found an increase in serum TNF- correlation with the incidence of $\mathrm{SCH}$ [13]. Serum TNF-levels are also associated with the level of symptoms of $\mathrm{SCH}$, increased serum TNF-levels are significantly correlated with more severe clinical symptoms in SCH [14]. However, Narla's research states that changes in brain chemistry and structure in $\mathrm{SCH}$ are caused by strong gene dysregulation so that not only microglia and TNF-play a role but can also respond to brain stem cells, neurons, and oligodendrocytes [15].

The neuroinflammatory process in $\mathrm{SCH}$ also occurs in infection. In COVID-19 infection, the virus is able to produce an exaggerated immune reaction in the host. In some cases, what is collectively called a "cytokine storm" occurs. Cytokine storm is an event of excessive inflammatory reaction in which there is rapid and large production of cytokines in response to an infection. In relation to COVID-19, it was found that there was a delay in the secretion of cytokines and chemokines by innate immune cells due to blockade by non-structural viral proteins. Furthermore, this leads to a spike in pro-inflammatory cytokines and chemokines

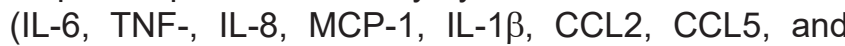
interferon) through activation of macrophages and lymphocytes. The release of these cytokines triggers the activation of adaptive immune cells such as $\mathrm{T}$ cells, neutrophils, and NK cells, along with the continued production of pro-inflammatory cytokines. This rapid surge of pro-inflammatory cytokines triggers inflammatory infiltration by lung tissue which causes lung damage to the epithelium and endothelium. This damage can lead to acute respiratory distress syndrome and multiorgan failure that can lead to death in a short time [16], [17].

Accordingly, chlorpromazine as an antipsychotic also has anti-viral and anti-inflammatory effects in schizophrenic patients with COVID-19, and the neuroinflammatory in $\mathrm{SCH}$ is very likely to occur in patients with COVID-19 infection [6], [18], [19]. Therefore, the researchers tried to examine the effectiveness of chlorpromazine on serum TNF-values in schizophrenic patients with COVID-19.

\section{Subjects and Methods}

This research is a nested case-control research, conducted at at the Mental Hospital "Dadi" South Sulawesi (Makassar, Indonesia). This research has received ethical approval from the Ethics Committee for Biomedical Research in Humans, Faculty of Medicine, Hasanuddin University, with Number: 341/ UN4.6.4.5.31/PP36/2021. All patients and families signed informed consent forms before inclusion in the study.

Research subjects were taken by consecutive sampling. The inclusion criteria were $\mathrm{SCH}$ sufferers according to DSM $\mathrm{V}$ and diagnosed with mildmoderate and asymptomatic COVID-19 based on the results of the reverse transcription-polymerase chain reaction (RT-PCR) swab examination. A 20-50 years old, currently hospitalized, receiving chlorpromazine therapy at a dose of 100-300 mg/day and a therapeutic dose of antipsychotic at least 4 weeks before the study, can communicate verbally and have psychotic clinical symptoms with a total positive and negative syndrome scale (PANSS) score <95 (mild) and willing to participate in the research. Exclusion criteria had a history of consuming and abusing psychotropic drugs, alcohol and narcotics, taking anti-inflammatory drugs or steroids, and having severe physical illness that was 
not caused or related to COVID-19. Dropout criteria if during the implementation of the study, there are side effects of treatment, the patient dies or the patient refuses to continue the study.

We recruited 80 subjects and then divided them into two groups. The first group, namely, $\mathrm{SCH}$ with COVID-19, consisted of 40 people receiving chlorpromazine at a dose of 100-300 mg/day, antipsychotics, COVID-19 therapy, and the second group, SCH without COVID-19, consisting of 40 people receiving chlorpromazine at a dose of 100-300 mg/ day, and antipsychotics alone for 4 weeks. Psychotic clinical symptoms were measured 3 times in 4 weeks (baseline, week 2, week, and week 4) using the PANSS and clinical global impression $\mathrm{SCH}(\mathrm{CGI}-\mathrm{SCH})$ scales. Serum TNF-levels were measured at baseline and at week 4 . This study was using more than 1 antipsychotic which is risperidone it $4 \mathrm{mg}$ and $6 \mathrm{mg}$ doses and haloperidol at $4.5 \mathrm{mg}, 7.5 \mathrm{mg}$, and $15 \mathrm{mg}$ doses.

TNF-levels were measured in the form of serum which was duplicated by the enzyme-linked immunosorbent essay (ELISA) method from a special TNF- $\alpha$ kit. The examination was carried out at the Hasanuddin University Medical Research Center Laboratory. The examination followed the instructions according to the human TNF- $\alpha$ ELISA kit protocol with product code RAB0476 Sigma-Aldrich Millipore brand. Blood samples were taken at the beginning of the study and after 4 weeks.

PANSS is a psychometric tool to assess positive, negative symptoms and general psychopathology. PANSS consists of 33 items, each of which is rated on a 7-point scale. After assessing each item, the accumulated value will be interpreted as follows: Mild pain $=58$, moderate pain $=75$, visible pain $=95$, severe pain $=116$, and very sick $=147$ [19].

$\mathrm{CGI} \mathrm{SCH}$ is a valid and reliable instrument in evaluating the severity and healing response of $\mathrm{SCH}$. CGI-SCH is a simpler scale because it only consists of two types, namely, the severity of the disease and the degree of change. The severity of the disease evaluates the mood during the week before the evaluation, whereas the severity of the change evaluates the change of the score. Each type contains five different ratings (positive, negative, mental stress, cognitive, and global) which are evaluated using a 7-point ordinal scale [20].

Possible side effects and complications with the administration of chlorpromazine may occur during the study. So far, the administration of chlorpromazine $100 \mathrm{mg} /$ day is well tolerated, and no clinical side effects have been detected. Two of the research subjects only experienced mild side effects in the form of tremors and could be controlled by administering an anticholinergic in the form of trihexyphenidyl.

\section{Results}

\section{Characteristics of research subjects}

This study began by screening the treatment group of SCH sufferers with COVID-19 who were hospitalized at the Hasanuddin University Teaching Hospital and its network from January 2021 to May 2021. Of the 131 schizophrenic patients with COVID-19 who were screened, 42 patients were found $(32.06 \%)$ met the inclusion criteria (Table 1). A total of 89 patients did not meet the inclusion criteria, namely, 24 patients aged more than 50 years, 13 patients with a total PANSS value $>96$, 41 patients did not receive chlorpromazine $100-300 \mathrm{mg} /$ day, seven patients had not been hospitalized for 3 months, and four patients taking anti-inflammatory due to skin disease. Among the 42 patients in the treatment group, only 40 patients completed until week 4 because two study subjects dropped out because they could be outpatients. Then, screening was carried out for the schizophrenic group without COVID-19 by adjusting the characteristics of the schizophrenic group with COVID19 to obtain homogeneity and obtained 40 patients in the control group.

Table 1: Characteristics of research subjects $(n=40)$

\begin{tabular}{|c|c|c|c|}
\hline \multirow[t]{2}{*}{ Variable } & $\begin{array}{l}\text { Schizophrenia } \\
\text { with COVID-19 }\end{array}$ & $\begin{array}{l}\text { Schizophrenia is } \\
\text { not COVID-19 }\end{array}$ & \multirow[t]{2}{*}{$\mathrm{p}$} \\
\hline & $\mathrm{n}=40$ & $\mathrm{n}=40$ & \\
\hline Age (mean $\pm S D)$ & $40.93 \pm 7.55$ & $40.25 \pm 8.10$ & 0.806 \\
\hline \multicolumn{4}{|l|}{ Gender (\%) } \\
\hline Male & $38(47.5)$ & $38(47.5)$ & \multirow[t]{2}{*}{1.000} \\
\hline Female & $2(2.5)$ & $2(2.5)$ & \\
\hline \multicolumn{4}{|l|}{ Education (\%) } \\
\hline No school & $10(12.5)$ & $11(13.8)$ & \multirow[t]{5}{*}{0.697} \\
\hline Elementary school & $16(20.0)$ & $17(21.2)$ & \\
\hline Junior high school & $4(5.0)$ & $1(1.2)$ & \\
\hline Senior high school & $9(11.2)$ & $9(11.2)$ & \\
\hline Undergraduate & $2(2.5)$ & $1(1.2)$ & \\
\hline \multicolumn{4}{|l|}{ Job (\%) } \\
\hline Does not work & $23(28.8)$ & $23(28.8)$ & \multirow[t]{5}{*}{0.786} \\
\hline Farmer & $13(16.2)$ & $10(12.5)$ & \\
\hline Private sector employee & $1(1.2)$ & $2(2.5)$ & \\
\hline Trader & $1(1.2)$ & $3(3.8)$ & \\
\hline Housewife & $2(2.5)$ & $2(2.5)$ & \\
\hline \multicolumn{4}{|l|}{ Antipsychotic per day (\%) } \\
\hline Risperidone $4 \mathrm{mg}$ & $15(18.8)$ & $24(28.8)$ & \multirow[t]{5}{*}{$0.023^{*}$} \\
\hline Risperidone 6 mg & $2(2.5)$ & $0(0.0)$ & \\
\hline Haloperidol $4.5 \mathrm{mg}$ & $4(5.0)$ & $5(6.2)$ & \\
\hline Haloperidol $7.5 \mathrm{mg}$ & $10(12.5)$ & $1(7.5)$ & \\
\hline Haloperidol $15 \mathrm{mg}$ & $9(11.2)$ & $11(13.8)$ & \\
\hline Equivalent dose of antipsychotic & $512 \pm 217.26$ & $522.5 \pm 239.48$ & 0.371 \\
\hline$($ Mean \pm SD) & & & \\
\hline Length of treatment days (Mean \pm SD) & $160.5 \pm 139.82$ & $153.25 \pm 132.75$ & 0.875 \\
\hline
\end{tabular}

There were no significant differences in age, gender, education, occupation, sedative antipsychotic dose, antipsychotic equivalent dose, and length of stay for SCH with COVID-19 and SCH without COVID-19 group $(p>0.05)$.

There was no significant difference in serum TNF-values with the level of clinical symptoms of COVID-19 ( $p>0.05)$. COVID-19 therapy received in the schizophrenic group with asymptomatic COVID-19 (33 patients) received azithromycin, oseltamivir, Vitamin C, and Vitamin D, but patients with mild symptoms (five patients) and moderate symptoms (two patients) received additional therapy with $\mathrm{N}$-acetylcysteine (Table 2). 
Table 2: Comparison of serum TNF-values with the level of clinical symptoms of COVID-19

\begin{tabular}{|c|c|c|c|c|c|}
\hline \multirow{2}{*}{$\begin{array}{l}\text { COVID-19 clinical } \\
\text { symptoms level }\end{array}$} & \multirow[t]{2}{*}{$\mathrm{n}(\%)$} & TNF- $\alpha$ baseline & \multirow[t]{2}{*}{$\mathrm{p}$} & TNF- $\alpha 4^{\text {th }}$ week & \multirow[t]{2}{*}{$\mathrm{p}$} \\
\hline & & Mean \pm SD & & Mean \pm SD & \\
\hline Asymptomatic & $33(82.5)$ & $25.07 \pm 3.13$ & 0.530 & $17.33 \pm 4.79$ & 0.706 \\
\hline Mild symptoms & $5(13)$ & $26.16 \pm 2.98$ & & $16.62 \pm 3.76$ & \\
\hline Moderate symptoms & $2(5)$ & $27.35 \pm 7.13$ & & $19.81 \pm 10.13$ & \\
\hline
\end{tabular}

Based on Table 3, it was found the results of routine hematology and blood chemistry examinations in the normal treatment group except for lymphocytopenia and neutropenia, and 34 study subjects $(85 \%)$ had bilateral pneumonia and 4 subjects $(10 \%)$ with unilateral pneumonia on computed tomography (CT) thorax examination results(Figure 1).

Table 3: Supporting examination results for the schizophrenic group with COVID-19

\begin{tabular}{llll}
\hline Hematology & Mean $\pm \mathrm{SD}$ & Units & Referral value \\
examination results & & & \\
\hline WBC & $7.44 \pm 1.93$ & $10^{3} / \mathrm{uL}$ & $3.17-8.40$ \\
$\mathrm{RBC}$ & $4.59 \pm 0.65$ & $10^{6} / \mathrm{uL}$ & $3.72-5.70$ \\
$\mathrm{HB}$ & $12.85 \pm 1.86$ & $\mathrm{~g} / \mathrm{dL}$ & $11.0-16.6$ \\
$\mathrm{HCT}$ & $38.01 \pm 5.34$ & $\%$ & $35.2-52.1$ \\
$\mathrm{MCV}$ & $82.81 \pm 6.41$ & $\mathrm{fL}$ & $86.1-102.4$ \\
$\mathrm{MCH}$ & $28.17 \pm 2.6$ & $\mathrm{pg}$ & $26.8-32.4$ \\
$\mathrm{MCHC}$ & $34.09 \pm 1.2$ & $\mathrm{~g} / \mathrm{dL}$ & $29.6-33.2$ \\
PLT & $276.63 \pm$ & $10^{3} / \mathrm{uL}$ & $167-390$ \\
& 64.06 & & \\
Neut & $9.58 \pm 15.37$ & $\%$ & $50-70$ \\
Lymp & $6.59 \pm 11.84$ & $\%$ & $20-40$ \\
Mono & $1.75 \pm 2.79$ & $\%$ & $2-8$ \\
Eos & $1.43 \pm 2.56$ & $\%$ & $0.02-0.05$ \\
Baso & $0.07 \pm 0.12$ & $\%$ & $0-0.06$ \\
GDS & $114.38 \pm$ & $\mathrm{mg} / \mathrm{dl}$ & $110-200$ \\
& 28.10 & & \\
Urea & $28.52 \pm 4.50$ & $\mathrm{mg} / \mathrm{dl}$ & $8.0-48.0$ \\
Creatine & $0.79 \pm 0.18$ & $\mathrm{mg} / \mathrm{dl}$ & $0.6-1.2$ \\
SGOT & $37.62 \pm 56.64$ & $\mathrm{U} / \mathrm{l}$ & $9-40$ \\
SGPT & $30.44 \pm 41.28$ & $\mathrm{U} / \mathrm{l}$ & $7-55$ \\
NLR & $1.89 \pm 0.98$ & & \\
CT thorax results & $\mathrm{n}(\%)$ & & \\
Normal & $2(5.0)$ & & \\
Bilateral pneumonia & $33(82.5)$ & & \\
Unilateral pneumonia & $4(10.0)$ & & \\
Bilateral & $1(2.5)$ & & \\
pneumonia+Effusion & & & \\
\hline WB Whe & & &
\end{tabular}

WBC: White blood cell, RBC: Red blood cell, HB: Hemoglobin, HCT: Hematocrit, MCV: Mean corpuscular volume, MCH: Mean corpuscular hemoglobin, MCHC: Mean corpuscular hemoglobin concentration, PLT glutamic pyruvic transaminase, NLR: Neutrophil-to-lymphocyte ratio, CT: Computed tomography.

\section{Comparison of serum TNF- $\alpha$ levels}

A total of 80 study subjects who received chlorpromazine 100-300 $\mathrm{mg} /$ day were measured for serum TNF-levels at the beginning of confirmed COVID-19 (baseline) and at week 4. The measurement results are shown in Table 4.

Table 4: Comparison of serum TNF-levels in the schizophrenic group with COVID-19 and the schizophrenic group without COVID-19

\begin{tabular}{|c|c|c|c|c|c|}
\hline \multirow[t]{4}{*}{$\begin{array}{l}\text { TNF- } \alpha \\
\text { serum }\end{array}$} & \multicolumn{2}{|c|}{$\begin{array}{l}\text { Schizophrenia with } \\
\text { COVID-19+ } \\
\text { chlorpromazine }\end{array}$} & \multicolumn{2}{|c|}{$\begin{array}{l}\text { Schizophrenia not } \\
\text { COVID-19+ } \\
\text { chlorpromazine }\end{array}$} & Control \\
\hline & \multicolumn{2}{|l|}{$n=40$} & \multicolumn{2}{|l|}{$n=40$} & $n=10$ \\
\hline & \multicolumn{2}{|l|}{$(\mathrm{pg} / \mathrm{ml})$} & \multicolumn{2}{|l|}{$(\mathrm{pg} / \mathrm{ml})$} & $(\mathrm{pg} / \mathrm{ml})$ \\
\hline & Mean \pm SD & $p$ & Mean \pm SD & $\mathrm{p}$ & Mean \pm SD \\
\hline Baseline & $25.32 \pm 3.26$ & $<0.001^{*}$ & $15.99 \pm 2.65$ & $0.281^{*}$ & $\begin{array}{l}13.67 \pm \\
1.47\end{array}$ \\
\hline $4^{\text {th }}$ week & $17.36 \pm 4.83$ & & $15.59 \pm 3.33$ & & \\
\hline
\end{tabular}

The comparison of baseline TNF-serum levels that increased in the schizophrenic group with
COVID-19 was $9.33 \mathrm{pg} / \mathrm{ml}$ higher, compared to the schizophrenic group without COVID-19. The decrease in TNF-levels in the schizophrenic group with COVID-19 of $7.96 \mathrm{pg} / \mathrm{ml}(p<0.001)$ indicated an improvement in TNF-serum levels at week 4. Meanwhile, there was no significant decrease in serum TNF- levels in the nonCOVID-19 schizophrenic group ( $p>0.05)$ (Figure 2).

\section{Total PANSS value comparison}

Comparison of Total PANSS values in the $\mathrm{SCH}$ with COVID-19 group and the SCH non-COVID-19 group measured in the initial week, $2^{\text {nd }}$ week, and $4^{\text {th }}$ week is shown in Table 5.

Table 5: Comparison of total PANSS values against the initial week, $2^{\text {nd }}$ week, and $4^{\text {th }}$ week in the schizophrenic group with COVID-19 and the schizophrenic group without COVID-19

\begin{tabular}{|c|c|c|c|c|}
\hline Treatment & $\begin{array}{l}\begin{array}{l}\text { Schizophrenia } \\
\text { with COVID-19 }\end{array} \\
n=40 \\
\end{array}$ & $\mathrm{p}$ & $\begin{array}{l}\text { Schizophrenia is } \\
\text { not COVID-19 } \\
\mathrm{n}=40 \\
\end{array}$ & $\mathrm{p}$ \\
\hline & Mean \pm SD & & Mean \pm SD & \\
\hline $\begin{array}{l}\text { PANSS early week } \\
\text { PANSS week } 2\end{array}$ & $\begin{array}{l}75.10 \pm 10.54 \\
73.13 \pm 10.55\end{array}$ & $<0.001^{*}$ & $\begin{array}{l}73.70 \pm 3.65 \\
71.70 \pm 3.62\end{array}$ & $<0.001^{*}$ \\
\hline PANSS week 4 & $69.18 \pm 10.36$ & & $69.75 \pm 3.84$ & \\
\hline
\end{tabular}
syndrome scale.

Based on the bivariate analysis using the Friedman test, in the schizophrenic group with COVID19 , the total PANSS value compared between the initial week, $2^{\text {nd }}$ week, and $4^{\text {th }}$ week showed a significant difference $(p<0.05)$. There is a decrease in the PANSS value which describes the improvement in clinical symptoms of schizophrenic patients after receiving therapeutic doses of antipsychotics and $100 \mathrm{mg}$ chlorpromazine.

In the non-COVID-19 schizophrenic group, the total PANSS value compared between the initial week, $2^{\text {nd }}$ week, and $4^{\text {th }}$ week showed a significant difference $(p<0.05)$. There is a decrease in the PANSS value which describes the improvement in clinical symptoms of schizophrenic patients after receiving therapeutic doses of antipsychotics and $100 \mathrm{mg}$ chlorpromazine (Figure 3).

\section{CGI-SCH value comparison}

Comparison of CGI-SCH values in the schizophrenic group with COVID-19 and the schizophrenic group without COVID-19 measured in the initial week, $2^{\text {nd }}$ week, and $4^{\text {th }}$ week as shown in Table 6.

Table 6: Comparison of $\mathrm{CGI}-\mathrm{SCH}$ values in the schizophrenic group with COVID-19 and the schizophrenic group without COVID-19 measured in the initial week, $2^{\text {nd }}$ week, and $4^{\text {th }}$ week

\begin{tabular}{|c|c|c|c|c|}
\hline Treatment & $\begin{array}{l}\begin{array}{l}\text { Schizophrenia } \\
\text { with COVID-19 }\end{array} \\
n=40 \\
\end{array}$ & $p$ & $\begin{array}{l}\text { Schizophrenia is } \\
\text { not COVID-19 } \\
\mathrm{n}=40 \\
\end{array}$ & $\mathrm{p}$ \\
\hline & Mean \pm SD & & Mean \pm SD & \\
\hline CGI-SCH early week & $21.03 \pm 2.97$ & $<0.001^{*}$ & $20.68 \pm 1.09$ & $<0.001^{*}$ \\
\hline CGI-SCH week 2 & $20.40 \pm 2.96$ & & $20.03 \pm 1.12$ & \\
\hline CGI-SCH week 4 & $19.35 \pm 2.79$ & & $19.43 \pm 1.08$ & \\
\hline
\end{tabular}


Based on bivariate analysis using the Friedman test, in the schizophrenic group with COVID-19, the $\mathrm{CGI}-\mathrm{SCH}$ values were compared between the initial week, $2^{\text {nd }}$ week, and $4^{\text {th }}$ week showing a significant difference $(p<0.05)$. There is a decrease in the CGI$\mathrm{SCH}$ value which describes the improvement in severity and healing response in schizophrenic patients with $\mathrm{SCH}$ after receiving therapeutic doses of antipsychotics and chlorpromazine $100 \mathrm{mg}$ (Figure 4).

In the non-COVID-19 schizophrenic group, the $\mathrm{CGI}-\mathrm{SCH}$ values compared between the initial week, $2^{\text {nd }}$ week, and $4^{\text {th }}$ week showed a significant difference $(p<0.05)$. There is a decrease in the CGI-SCH value which describes the improvement in severity and healing response in schizophrenic patients with $\mathrm{SCH}$ after receiving therapeutic doses of antipsychotics and chlorpromazine $100 \mathrm{mg}$.

\section{Discussion}

This study was conducted to test the effectiveness of chlorpromazine on serum TNF-levels in schizophrenic patients with COVID-19 as well as total PANSS and CGI-SCH values for 4 weeks. The basic characteristics of the research subjects including age, sex, education, occupation, equivalent dose of antipsychotic, and length of hospitalization were not found to be significantly different between the treatment group and the control group ( $p>0.05)$. However, there was a significant difference between the treatment group and the control group $(p=0.023)$. Thus, the research subjects are quite homogeneous.

The mean age of the research subjects was $40.93 \pm 7.55$ in the treatment group and $40.25 \pm 8.10$ in the control group with more males than females. According to the theory, the prevalence of $\mathrm{SCH}$ in men and women is the same. However, there are differences in the onset and course of the disease. Earlier onset was found in the male sex. Where more than half of people with $\mathrm{SCH}$ are men, but only a third are women and were first treated before the age of 25 years. Peak age of onset is $10-25$ years for men and 25-35 years for women [21].

There are several hypotheses that can explain the sex differences in $\mathrm{SCH}$. The theory of $\mathrm{SCH}$ involves gonadal hormones, such as estrogen, which play a neuroprotective role preventing the pathology of $\mathrm{SCH}$ in women. Estrogen deficiency at menopause is strongly associated with the severity of psychiatric symptoms in women. A negative correlation between patients' plasma estrogen levels and symptoms of $\mathrm{SCH}$ was also reported in men. Recent research has shown that sex chromosomes, $\mathrm{XX}$ or $\mathrm{XY}$, can play a role in neurodevelopment in the form of a short arm proximal to the $\mathrm{X}$ chromosome, which is often found in people with $\mathrm{SCH}$. Gender-specific associations of certain dopaminergic genes (catechol-O-methyltransferase and monoamine oxidase) are also associated with $\mathrm{SCH}$. Meanwhile, dopamine deficits and excesses have been associated with positive and negative $\mathrm{SCH}$ symptoms in general [22].

Most of the last education level of people with $\mathrm{SCH}$ in this study was elementary school and did not finish elementary school. Children and adolescents who suffer from $\mathrm{SCH}$ have academic and mathematics achievement that is much worse than individuals who are not schizophrenic. Individuals with $\mathrm{SCH}$ are also less likely to have higher education than individuals without $\mathrm{SCH}$. In addition, adolescents are considered at risk for $\mathrm{SCH}$ because they have a history of premorbid psychotic-like experiences or have family members with severe mental disorders. Poor academic performance before age 16 associated with the appearance of prodromal symptoms may represent a premorbid cognitive marker that is susceptible to $\mathrm{SCH}$ later in life [23].

In this study, $57.6 \%$ of the research subjects did not work. There are several criteria of job function that need to be considered in people with $\mathrm{SCH}$, namely, the work is paid or not, part time or full time. Most people with SCH often work without pay at home. However, 10-20\% of people with $\mathrm{SCH}$ can also work competitively, where the job requires a normal recruitment process and is not part of a job program created by a social company such as job training for people with mental disorders. People with $\mathrm{SCH}$ who are employed in normal jobs, generally get laid off because the company is dissatisfied with the results of the work they do [24].

The administration of antipsychotic therapeutic doses in this study was dominantly using haloperidol $4.5-15 \mathrm{mg} /$ day $(57.5 \%)$ in the schizophrenic group with COVID-19, while risperidone 4-6 mg/day (60\%) in the schizophrenic group without COVID-19. The use of haloperidol and risperidone is an antipsychotic therapy option used in inpatients at the Dadi Regional Special Hospital, South Sulawesi Province. The typical antipsychotic haloperidol having a strong affinity for the D2 receptor was suggested as a potential effective treatment for COVID-19 based on in vitro assays through the Sigma 1 and Sigma 2 receptors. Molecules targeting the Sigma receptor can reduce viral infectivity through different mechanisms, including remodeling, lipids, and endoplasmic reticulum stress response [25].

However, a study by Hoertel et al. at Greater Paris University Hospitals examining the association of haloperidol use with intubated patients with COVID-19 concluded that there was no significant relationship between daily haloperidol dose and duration of exposure in the haloperidol exposed group of patients [26]. This research is the basis that the administration of haloperidol has no effect on the symptoms of COVID-19. 
Equivalent dose ratio of antipsychotic therapy obtained in the treatment group was $512 \pm 217.26$ and in the control group was $522.5 \pm 239.48$. The calculation of this equivalent dose ratio is based on the International Consensus on Antipsychotic Doses using chlorpromazine as a comparison. Haloperidol $1 \mathrm{mg}$ has a chlorpromazine ratio of $60 \mathrm{mg}$, while risperidone $1 \mathrm{mg}$ has a chlorpromazine ratio of $100 \mathrm{mg}$ [27] so that in the treatment group, the average equivalent of haloperidol was $8.5 \mathrm{mg} /$ day and the control group was equivalent to an average of $5.2 \mathrm{mg} / \mathrm{day}$ risperidone. This range corresponds to therapeutic doses of haloperidol 5-10 mg/day and risperidone 4-6 mg/day.

Demographic characteristics also affect TNF- $\alpha$ levels. Gender has an influence on TNF-levels in psychiatric patients, female serum TNF-levels are higher in men. The mean body mass index and smoking frequency also increased TNF- $\alpha$ levels. A history of antipsychotic treatment also gave a decrease in TNFlevels in 4 weeks compared to patients not taking antipsychotics. History of comorbid disease is the most frequent confounding factor in assessing proinflammatory cytokines. A diagnosis of depression has higher serum TNF-levels than a diagnosis of SCH [28]. In research subjects during hospitalization, it is difficult to get access to smoking because it is prohibited while in hospital.

This study found 131 schizophrenic patients with COVID-19 who were hospitalized from January 2021 to May 2021. Psychiatric inpatients have a high risk of exposure to COVID-19 because patients live in adjacent rooms, are free to interact with other patients, and use shared bathrooms [29]. In addition, patients have difficulty maintaining health protocols such as social distancing and hand washing due to cognitive deficits, disorganized thinking, behavioral dysregulation, and poor insight. To minimize the risk of inpatients having direct contact with visitors, restrictions are placed on family members, health workers, and field practice students [30].

Previous studies have examined the prevalence of mental disorders sufferers who are sick with COVID-19 abroad. In a study at New York University, there were 75 patients with $\mathrm{SCH}$ spectrum disorder who were confirmed positive for COVID-19 and 20 of them died. This makes $\mathrm{SCH}$ a high-risk factor for mortality in COVID-19 patients [3]. A study in France with a period of February-June 2020 of 50,750 COVID19 patients treated in the ICU, there were $823 \mathrm{SCH}$ sufferers $(1.6 \%)$. It was also found in the same study that age $<55$ years had a higher risk of being admitted to the ICU [31].

A study in Korea with a period from January to May 2020 found 128 (9.7\%) of 1320 people with mental disorders who were sick with COVID-19. Patients with severe mental illness had a slightly higher risk of clinically severe COVID-19 than patients without a history of mental disorders. Doctors treating patients with COVID-19 should be aware of the risks associated with pre-existing mental illness [32].

The study with the largest population was conducted in the USA with 61.7 million adults in the electronic health database, found 1.3 million $(2.1 \%)$ people with mental disorders. There were 5450 patients with mental disorders with COVID-19 and 120 people with $\mathrm{SCH}(0.8 \%)$. It was also found that people with mental disorders with COVID-19 infection had an $8.5 \%$ increased risk of death compared to $5.7 \%$ for all COVID-19 patients and $4.7 \%$ for COVID-19 patients without mental disorders [33].

Patients with severe mental disorders and comorbidities have a higher risk for more severe COVID-19 disease. Hence, it is important to conduct personalized COVID-19 clinical management and health-care strategies before, during, and after hospitalization to reduce health disparities in the severe mental disorder population.

This study evaluates routine hematological examinations and blood chemistry of a group of $\mathrm{SCH}$ sufferers with COVID-19 without symptoms and mild symptoms. All 40 study subjects in the treatment group have normal results on all routine blood examinations, neutrophil-lymphocyte ratio, blood when, serum glutamic oxaloacetic transaminase, serum glutamic pyruvic transaminase, urea, and creatine, but they have neutropenia and lymphocytopeni. Several retrospective studies assessed the parameters of routine hematological examination in asymptomatic and mildly symptomatic COVID-19 patients. The study in Wuhan, China, on 74 asymptomatic COVID-19 patients, the majority of the results were normal in WBC, $\mathrm{Hb}$, and platelets, but found lymphocytopenia and neutropenia [34].

Decreased lymphocyte levels were reported in 20 of 29 COVID-19 patients [35]. Another study with 138 COVID-19 patients had the same lymphocytopenia as SARS-CoV and MERS-CoV [36]. A study with 41 COVID-19 patients, 63 patients experienced lymphocytopenia [37]. Several hematological changes were reported in COVID-19 patients, including leukocytosis, decreased lymphocyte values, increased D-Dimer levels, neutrophilia, thrombocytopenia, eosinopenia, and basopenia. Moreover, patients with moderate-to-severe symptoms have more prominent hematological abnormalities than patients with mild and asymptomatic symptoms [38].

Lymphopenia is characteristically abnormal hematologically found in SARS-CoV and MERS-CoV infections and is associated with disease severity. These findings suggest that lymphopenia can be considered as a surrogate biomarker of the adaptive immune response to SARS-CoV-2. The biological reasons associated with lymphopenia are still under investigation and may be due to dysregulation of the cytokine system [39]. 
Neutrophil-to-lymphocyte ratio (NLR) and lymphocyte-monocyte ratio are both parameters that can be calculated quickly from routine blood tests. An increase in NLR 3.13 leads to a poor prognosis. The NLR describes the balance of the body's innate (neutrophil) and adaptive (lymphocyte) immune responses. In this study, it was found that the NLR was $1.89 \pm 0.98$, so it was sufficient to self-isolate. If asymptomatic patients are not properly identified and quarantined, they can become a source of infection and cause disease transmission. Thus, self-isolation is recommended for asymptomatic patients.

This study also evaluated CT thoracic examination, found that 34 study subjects $(85 \%)$ had bilateral pneumonia and 4 subjects $(10 \%)$ had unilateral pneumonia. Several studies have also reported that asymptomatic and mildly symptomatic COVID-19 patients still have abnormal CT thoracic. The study in Wuhan, China, found 52 patients (20.6\%) of unilateral pneumonia and $119(47.2 \%)$ of bilateral pneumonia [34]

Another study in Wuhan, 36 asymptomatic patients found pneumonia on CT thorax [40]. In a study in Chongqing China, 42 patients (68.9\%) were asymptomatic and had mild symptoms with CT thoracic abnormalities [38]. A total of 178 patients with mild symptoms of COVID-19 have the main symptom experienced was cough [34]. The same thing was experienced by patients who were research subjects who experienced mild symptoms. The study found that patients were more likely to be asymptomatic if they met one or more of the following criteria: Young age, unilateral pneumonia, and achieved virus-free status within 5 days [34]. In a study in Jinan China, 11 asymptomatic patients with young age were detected with abnormal CT thorax results, and statistically, there was no significant difference compared to the moderately severe symptomatic group [41].

A total of 80 study subjects who received chlorpromazine 100-300 mg/day were measured for serum TNF-levels at the beginning of confirmed COVID-19 (baseline) and at week 4. Serum TNF- $\alpha$ level is a biomarker used in this study. It was found that baseline serum TNF-levels were increased in the schizophrenic group with COVID-19, compared to the schizophrenic group without COVID-19. The decrease in TNF- levels in the schizophrenic group with COVID-19 ( $p<0.001)$ indicated an improvement in serum TNF- levels at week 4. Meanwhile, there was no significant decrease in serum TNF- levels in the schizophrenic group without COVID-19 ( $p>$ 0.05).

In the non-COVID-19 schizophrenic group, the average baseline serum level was $15.99 \pm 2.65 \mathrm{pg} / \mathrm{ml}$, and in the $4^{\text {th }}$ week, it was $15.59 \pm 3.33 \mathrm{pg} / \mathrm{ml}$. Biomarkers of TNF- levels in $\mathrm{SCH}$ describe the process of neuronmicroglia interactions in the pathophysiology of
$\mathrm{SCH}$ [42]. Several studies have found different levels of TNF-in schizophrenic patients. This is due to different reagents, different blood sampling times, and different research subjects. The study by Naudin obtained an average TNF- of $34 \mathrm{pg} / \mathrm{ml}$ and increased in patients with chronic SCH [43].

A study by $\mathrm{Kim}$ in Korea found an average TNF- of $870.82 \mathrm{pg} / \mathrm{ml}$ in schizophrenic patients and $577.51 \mathrm{pg} / \mathrm{ml}$ in normal controls, and schizophrenic patients after hospitalization and then reexamined when they returned home, TNF- $\alpha$ levels decreased to an average $850.97 \mathrm{pg} / \mathrm{ml}$ [44]. An increased inflammatory response is implicated in the pathophysiology of $\mathrm{SCH}$, and antipsychotic drugs may be involved in the treatment of $\mathrm{SCH}$. It is also possible that some antipsychotics have anti-inflammatory activity as it was found in Kim's study that the pro-inflammatory cytokines IL-6 and TNF-a were significantly reduced after 6 weeks of treatment with antipsychotics [44].

A study by Luo et al. at Guangzhou Hospital examined changes in serum TNF-, IL-18, and IL-6 in 68 chronic schizophrenic patients at the beginning of hospitalization and at discharge, found a significant decrease in TNF- levels from $12.15 \mathrm{pg} / \mathrm{ml}$ to $11.30 \mathrm{pg} / \mathrm{ml}$. Meanwhile, in normal control people, TNF- levels were $2.24 \mathrm{pg} / \mathrm{ml}$ [45]. This study is closest to the results of the research conducted.

The latest study by Mesa in Spain on 60 COVID-19 patients found 29 ARDS patients with a mean TNF- level of $20.89 \mathrm{pg} / \mathrm{ml}$ and 31 non-ARDS patients with an average TNF- level of $8.58 \mathrm{pg} / \mathrm{ml}$. TNF- values were also significantly increased in ARDS compared with non-ARDS patients a week after admission, indicating the presence of high systemic inflammation. This study also found that the TNF- biomarker had a sensitivity of $48.3 \%$ and a specificity of $73.3 \%$. Determining TNF- levels together with IL-6 can be considered as an important tool for classifying highrisk patients and planning therapy [46]. These data on TNF- levels as a comparison were due to the lack of publication of TNF- $\alpha$ levels in schizophrenic patients with COVID-19 who received antipsychotics, especially chlorpromazine.

The study by Himmerich investigated the effect of several antipsychotics on pro-inflammatory cytokines in vitro with chlorpromazine at a dose of $75 \mathrm{mg} /$ day TNF- levels $1.82 \mathrm{pg} / \mathrm{ml}$, a dose of $150 \mathrm{mg} /$ day TNF- levels $1.56 \mathrm{pg} / \mathrm{ml}$, a dose of $300 \mathrm{mg} /$ day $1.77 \mathrm{pg} / \mathrm{ml}$, and $600 \mathrm{mg} /$ day $1.71 \mathrm{pg} /$ $\mathrm{ml}$ [12]. So that TNF- levels reached peak levels after administration of chlorpromazine $75 \mathrm{mg} /$ day and decreased TNF- levels with increasing doses of chlorpromazine.

The results showed the decrease in TNFlevels in the schizophrenic group with COVID-19 with an average of $7.95 \pm 2.28 \mathrm{pg} / \mathrm{ml}$. This is in accordance with the study in Medan, in Schizophrenic patients, 
the decrease in TNF- levels averaged $3.40 \mathrm{pg} / \mathrm{ml}$ [47]. Decreased levels of TNF- provide scientific evidence for antipsychotics chlorpromazine reduces serum levels of the pro-inflammatory cytokine TNF- as well as anti-viral through clathrin- and dynamin-dependent inhibitory mechanisms in SARS-CoV-2 [18], [48]. Chlorpromazine blocks the entry of the SARS-CoV-2 virus into cells by inhibiting the activation of lysosomal proteases that allow viral fusion with endosomes and the release of viral genetic material into the cytosol [18].

One of the advantages of chlorpromazine over other antivirals lies in its biodistribution. In animal experiments that after a single injection of chlorpromazine, the highest concentrations of the molecule and its metabolites were detected in the lungs, with doses of chlorpromazine 20-200 times higher than in the blood [6]. These results were confirmed in humans in a postmortem study of schizophrenic patients treated with chlorpromazine. Chlorpromazine is also highly concentrated in saliva, with concentrations $30-100$ times higher than in human plasma. High concentrations of chlorpromazine in the salivary glands can reduce the salivary viral load and therefore reduce the transmission of SARS-CoV-2 [6].

Chlorpromazine has lipophilic properties so it can cross the blood-brain barrier and therefore can have a therapeutic or prophylactic effect on the neurological form of COVID-19. The cerebral distribution of chlorpromazine has been known for a long time and underlies its use for its antipsychotic action. In vitro studies, chlorpromazine was detected in brain tissue 15 min after a single intravenous injection, in different brain areas including cortex, caudate nucleus, putamen, and thalamus. In chronic administration to rats, the concentration of chlorpromazine in the brain has been found to be up to 25 times higher than in plasma [49].

Chlorpromazine, already routinely used in psychiatry, has an excellent tolerance profile. Side effects are known, including: Anticholinergic effects (sedation, dry mouth, constipation, and urinary retention), increased QT, and neuroleptic malignancy syndrome are a rare condition. Side effects of orthostatic and neurologic hypotension such as parkinsonism, tremor, akathisia, and dystonia are well managed with dose reduction or drug changes [50]. During this study, the only side effects that appeared were tremors and could be controlled by administering an anticholinergic in the form of trihexyphenidyl.

The critical question of what dose of chlorpromazine is required to achieve a clinically relevant anti-SARS-CoV-2 effect in humans remains unresolved because it is difficult to estimate the effective in vivo dose from the effective in vitro dose and there are no animal data in this regard. Anti-coronavirus effect of chlorpromazine. This study uses a dose of chlorpromazine $100 \mathrm{mg} / \mathrm{day}$ and is expected to be a reference for further research regarding the appropriate dose of chlorpromazine in schizophrenic patients with COVID-19.

However, it is important to note that the decrease in serum TNF- levels in the treatment group cannot be claimed as an effect of chlorpromazine itself because the study subjects in the treatment group also received COVID-19 therapy in the form of antibiotics (azithromycin) and anti-viral (oseltamivir). Azithromycin is an antiviral and immunomodulator in the treatment of COVID-19. The use of these macrolides has been associated with improved clinical outcomes in other viral infections and CAP. Azithromycin has shown activity in vitro against SARS-CoV-2 and acts at several viral sites. Furthermore, azithromycin immunomodulation enhances clinical improvement in severe COVID19 , the ability to downregulate cytokine production, maintains epithelial integrity, and prevents pulmonary fibrosis. It may play a role in the hyperinflammatory stage of COVID-19 [51].

In this study, there was a combination of azithromycin and oseltamivir therapy. Lee et al. concluded that in hospitalized patients with influenza A pneumonia, the combination of azithromycin to oseltamivir significantly reduced pro-inflammatory cytokine synthesis, with a trend toward faster resolution of symptoms [52]. In this study, there was also a combination of azithromycin and chlorpromazine which is the same group of phenothiazines as hydroxychloroquine. In a randomized-controlled clinical trial in hospitalized patients with mild-tomoderate COVID-19, the use of hydroxychloroquine and azithromycin or hydroxychloroquine alone did not improve clinical status at 15 days compared with standard care [53]. As well as the side effects of cardiotoxicity often encountered in azithromycin combination hydroxychloroquine [51].

In vitro study of a combination of antiviral, antibiotics, and hydroxychloroquine therapy against SARS-CoV-2 isolated from COVID-19 patients in Surabaya. Measurements were made at several levels of cytokines. TNF- levels had no effect on azithromycin monotherapy and hydroxychloroquine monotherapy.

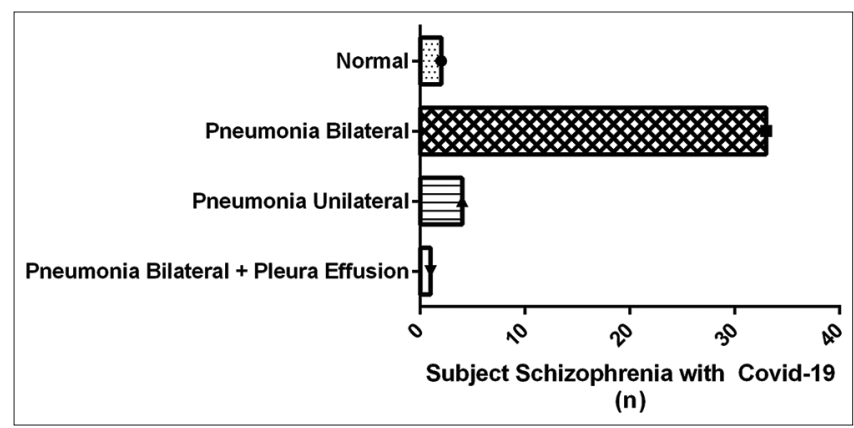

Figure 1: Results of thorax computed tomography scan of schizophrenic patients with coronavirus disease 2019 


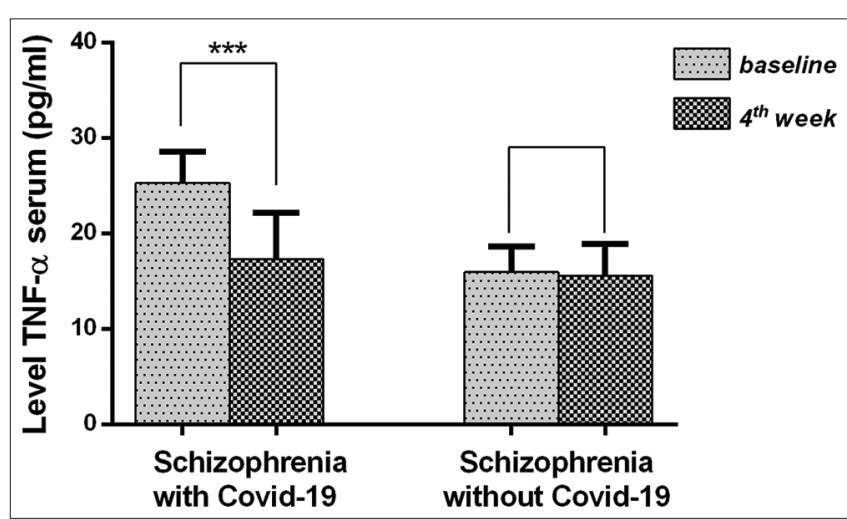

Figure 2: Comparison of serum tumor necrosis factor-levels in the schizophrenic group with coronavirus disease 2019 (COVID-19) and the schizophrenic group without COVID-19. All data are presented by mean with $S D,{ }^{* * *} p<0.001$ (Paired t-test)

However, the combination of azithromycin and hydroxychloroquine reduced TNF- levels by $25 \mathrm{~g} / \mathrm{mL}$ in $24 \mathrm{~h}$ [54]. Hydroxychloroquine and azithromycin affect the drug's ability to inhibit or reduce the level of viral infectivity in host cells. This is predicted due to the interaction of ligands and proteins called molecular docking. This interaction can be seen from the binding site of the target macromolecule consisting of the docking algorithm stage and the scoring function so as to get the affinity value [55]. A low affinity value indicates that the conformation formed is stable, while a high affinity indicates the formation of a less stable complex. The more negative the resulting value, the stronger the affinity of the protein-ligand complex, so it is hoped that the activity will be of higher quality [56].

This supports our study which found that TNF-levels in the schizophrenic group without COVID-19 did not decrease due to chlorpromazine monotherapy, while the schizophrenic group with COVID-19 experienced a significant decrease in TNF- levels due to the combination of azithromycin as COVID-19 therapy and chlorpromazine as antipsychotic therapy.

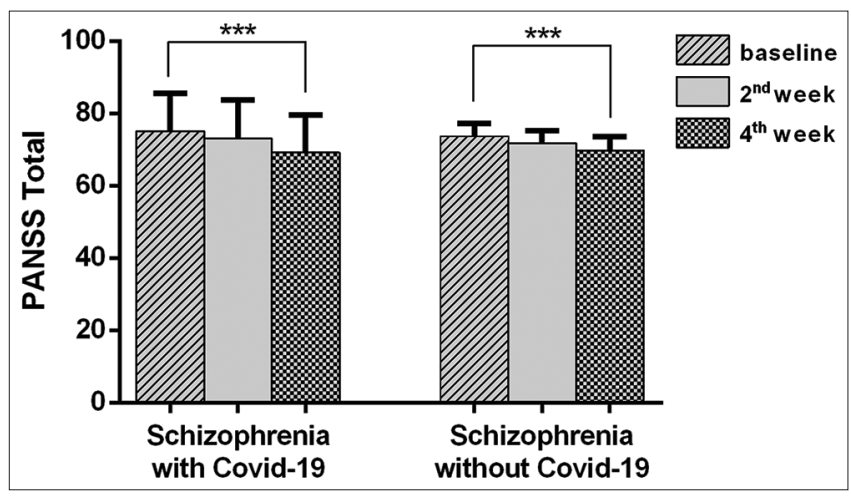

Figure 3: Comparison of total positive and negative syndrome scale scores against the initial week, $2^{\text {nd }}$ week, and $4^{\text {th }}$ week in the schizophrenic group with coronavirus disease 2019 (COVID-19) and the schizophrenic group without COVID-19

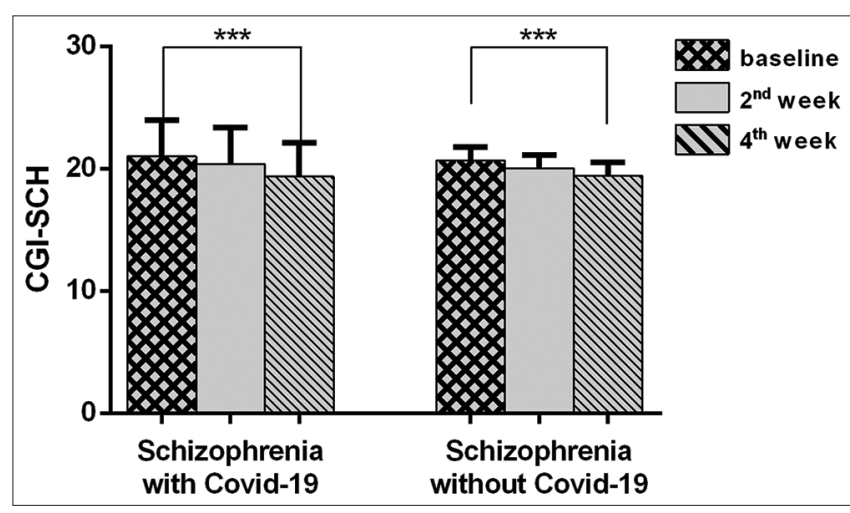

Figure 4: Comparison of clinical global impression schizophrenia values against the initial week, $2^{\text {nd }}$ week, and $4^{\text {th }}$ week in the schizophrenic group with coronavirus disease 2019 (COVID-19) and schizophrenia without COVID-19. All data are presented by mean with $S D .{ }^{* * *} p<0.001$ (Friedman test)

\section{Conclusion}

The serum TNF- value of schizophrenic patients with COVID-19 is higher than schizophrenic patients without COVID-19. Coadministration of chlorpromazine, antipsychotics, and COVID-19 therapy reduces serum TNF- values in schizophrenic patients with COVID-19. The administration of chlorpromazine and antipsychotic in therapeutic doses reduced the total PANSS and CGI-SCH values.

\section{References}

1. WHO. Clinical Management of Severe Acute Respiratory Infection when Novel Coronavirus (nCoV) Infection is Suspected. Geneva: WHO; 2020. Available from: https://www. who.int/internal-publications-detail/clinical-management-ofsevere-acute-respiratory-infection-when-novel-coronavirus(ncov)-infection-is-suspected [Last accessed on 2020 Apr 21]

2. Coccolini F, Sartelli M, Kluger Y, Pikoulis E, Karamagioli E, Moore E. COVID-19 the showdown for mass casualty preparedness and management: The cassandra syndrome. World J Emerg Surg. 2020;15(1):26. https://doi.org/10.1186/ s13017-020-00304-5

PMid:32272957

3. Katlyn N, Chenxiang L, Mark O. Association of psychiatric disorders with mortality among patients with COVID-19. JAMA Psychiatry. 2021;78(4):1-7.

4. Hoertel N, Sachez-Rico M, Vernet R, Jannot AS, Neuraz A, Blanco C, et al. Observational study of chlorpromazine in hospitalized patients with COVID19. Clin Drug Investig. 2021;41(3):221-33. https://doi.org/10.1007/s40261-021-01001-0 PMid:33559821

5. Arana GW. Antipsychotic Drugs in Handbook of Psychiatric Drug Therapy. Philadelphia, PA: Lippincot Williams \& Wilkins; 2000.

6. Plaze M, Attali D, Petit A, Blatzer M, Simon-Loriere E, Vinckier F. Repurposing chlorpromazine to treat COVID-19: The reCoVery study. Encephale. 2020;46(3):169-72. https://doi.org/10.1016/j. encep.2020.05.006 


\section{PMid:32425222}

7. Dyall J, Coleman C, Hart B, Venkataraman T, Holbrook M, Kindrachuk J. Repurposing of clinically developed drugs for treatment of Middle East respiratory syndrome coronavirus infection. Antimicrob Agents Chemother. 2014;58(8):4885-93. https://doi.org/10.1128/AAC.03036-14

PMid:24841273

8. DeWilde A, Jochmans D, Posthuma C, Zevenhoven-Dobbe J, van Nieuwkoop S, Bestebroer T. No TitleScreening of an FDAapproved compound library identifies four small-molecule inhibitors of Middle East respiratory syndrome Coronavirus replication in cell culture. Am Soc Microbiol. 2014;8:4875-84. https://doi.org/10.1128/AAC.03011-14

PMid:24841269

9. Daniel J, Chau N, Abdel-Hamid M, Hu L, VonKleist L, Whiting A. Phenothiazine-derived antipsychotic drugs inhibit dynamin and clathrin-mediated endocytosis. Traffic. 2015;16:635-54. https:// doi.org/10.1111/tra.12272

PMid:25693808

10. Miller B, Buckley P, Seabolt W, Mellor A, Kirkpatrick B. Metaanalysis of cytokine alterations in schizophrenia: Clinical status and antipsychotic effects. Biol Psychiatry. 2011;70(7):663-71. https://doi.org/10.1016/j.biopsych.2011.04.0

PMid:21641581

11. Bertini R, Garattini S, Delgado R, Ghezzi P. Pharmacological activities of chlorpromazine involved in the inhibition of tumour necrosis factor production in vivo in mice. Immunology. 1993;79:217-9

PMid:8102118

12. Himmerich $\mathrm{H}$, Schonherr J, Fulda S, Sheldrick AJ, Bauer K, Sack U. Impact of antipsychotics on cytokine production in vitro. J Psychiatr Res. 2011;45(10):1358-65. https://doi.org/10.1016/j. jpsychires.2011.04.009

PMid:21592521

13. Lee EE, Hong S, Martin AS, Eyler LT, Jeste DV. Inflammation in schizophrenia: Cytokine levels and their relationships to demographic and clinical variables. Am J Geriatr Psychiatry. 2017;25(1):50-61. https://doi.org/10.1016/j.jagp.2016.09.009 PMid:27840055

14. Suchanek-Raif $R$, Raif $P$, Kowalczyk M, Paul-Samojedny $M$, Kucia K, Merk W. Promoter polymorphisms of TNF-a gene as a risk factor for schizophrenia. Arch Med Res. 2018;49:248-54. https://doi.org/10.1016/j.arcmed.2018.09.007. PMid:30268704

15. Narla S, Lee Y, Benson C, Sarder P, Brennand K, Stachowiak E. Common developmental genome deprogramming in schizophrenia-role of integrative nuclear FGFR1 signaling (INFS). Schizophr Res. 2017;185:17-32. https://doi. org/10.1016/j.schres.2016.12.012

PMid:28094170

16. Gennaro F, Pizzol D, Marotta C, Antunes M, Racalbuto V, Veronese $\mathrm{N}$, et al. Coronavirus diseases (COVID-19) current status and future perspectives: A narrative review. Int J Environ Res Public Health. 2020;17(8):2690. https://doi.org/10.3390/ ijerph17082690

PMid:32295188

17. Malavika L, Goyal T, Ghosh R, Suri S, Mitra P. Inflammation, immunity and immunogenetics in COVID-19: A narrative review. Indian J Clin Biochem. 2020;35(3):260-73. https://doi. org/10.1007/s12291-020-00897-3 PMid:32641873

18. Stip E, Rizvi TA, Farah Mustafaa SJ, Aburuz S, Ahmed NN, Aziz KA, et al. The large action of chlorpromazine: Translational and transdisciplinary considerations in the face of COVID-19. Front Pharmacol. 2020;11:577678. https://doi.org/10.3389/

\section{fphar.2020.577678}

PMid:33390948

19. Leucht S, Kane J, Kissling W, Hamann J, Etschel E, Engel R. What does the PANSS mean? Schizophr Res. 2005;79(23):231-8. https://doi.org/10.1016/j.schres.2005.04.008 PMid:15982856

20. Haro J, Kamath S, Ochoa S. The clinical global impressionschizophrenia scale: Asimple instrument to measure the diversity of symptoms present in schizophrenia. Acta Psychiatr Scand. 2003;107(416):16-23. https://doi.org/10.1034/j.1600-0447.107. s416.5.x

PMid: 12755850

21. Sadock B, Sadock V, Ruiz P. Schizophrenia spectrum and other psychotic disorder. In: Kaplan and Sadock's Synopsis of Psychiatry Behavioural Sciences/Clinical Psychiatry. $11^{\text {th }}$ ed. Philadelphia, PA: Lippincott Williams \& Wilkins; 2015. p. 300-23.

22. Li R, Ma X, Wang G, Yang J, Wang C. Why sex differences in schizophrenia? J TransI Neurosci (Beijing). 2016;1(1):37-42. PMid:29152382

23. Dickson H, Hedges E, Ma S, Cullen A, MacCabe J, Kempton M. Academic achievement and schizophrenia: A systematic metaanalysis. Psychol Med. 2020;50(12):1949-65. https://doi. org/10.1017/S0033291720002354

PMid:32684198

24. Davidson L, Schmutte T, Dinzeo T, Andres-Hyman R. Remission and recovery in schizophrenia: Practitioner and patient perspectives. Schizophr Bull. 2008;34(1):5-8. https://doi. org/10.1093/schbul/sbm122

PMid: 17984297

25. Vela J. Repurposing sigma-1 receptor ligands for COVID19 therapy? Front Pharmacol. 2020;11:1716. https://doi. org/10.3389/fphar.2020.582310 PMid:33364957

26. Hoertel N, Sanchez-Rico M, Vernet R, Jannot A, Neuraz A, Blanco C. Observational study of haloperidol in hospitalized patients with COVID-19. PLoS One. 2021;16(2):e0247122. https://doi.org/10.1371/journal.pone.0247122 PMid:33606790

27. Gardner D, Murphy A, O'Donnel H, Centorrino F, Baldessarini R. International consensus study of antipsychotic dosing. Am J Psychiatry. 2010;167(6):686-93. https://doi.org/10.1176/appi. ajp.2009.09060802

PMid:20360319

28. Haack $M$, Hinze-Selch $D$, Fenzel $T$, Kraus $T$, Kuhn $M$, Schuld A, et al. Plasma levels of cytokines and soluble cytokine receptors in psychiatric patients upon hospital admission: Effects of confounding factors and diagnosis. J Psychiatr Res. 1999;33(5):407-18. https://doi.org/10.1016/ s0022-3956(99)00021-7 PMid:10504009

29. Li L. Challenges and priorities in responding to COVID-19 in inpatient psychiatry. Psychiatr Serv. 2020;71(6):624-6. https:// doi.org/10.1176/appi.ps.202000166 PMid:32321388

30. CDC. Implementation of Mitigation Strategies for Communities with Local COVID-19 Transmission. Atlanta, Georgia, United States: CDC; 2020. Available from: https://www.cdc.gov/ coronavirus/2019-ncov/downloads/community-mitigationstrategy.pdf [Last accessed on 2021 Aug 14].

31. Fond G, Pauly V, Leone M, Llorca P. Disparities in intensive care unit admission and mortality among patients with schizophrenia and COVID-19: A national cohort study. Schizophr Bull. 2020;47(3):624-34. https://doi.org/10.1093/schbul/sbaa158 PMid:33089862 
32. Lee S, Yang J, Moon S, Yoo I, Ha E. Association between mental illness and COVID-19 susceptibility and clinical outcomes in South Korea: A nationwide cohort study. Lancet Psychiatry. 2020;7(12):1025-31. https://doi.org/10.1016/ S2215-0366(20)30421-1 PMid:32950066

33. Wang $\mathrm{Q}$, Xu R, Volkow N. Increased risk of COVID-19 infection and mortality in people with mental disorders: Analysis from electronic health records in the United States. World Psychiatry. 2021;20(1):124-30. https://doi.org/10.1002/wps.20806 PMid:33026219

34. Li Y, Shi J, Xia J, Duan J, Chen L, Yu X. Asymptomatic and symptomatic patients with non-severe Coronavirus disease (COVID-19) have similar clinical features and virological courses: A retrospective single center study. Front Microbiol. 2020;11:1570. https://doi.org/10.3389/fmicb.2020.01570.

PMid:32754137

35. Cheng JL, Huang C, Zhang GJ, Liu DW, Li P, Lu CY. Epidemiological characteristics of novel coronavirus pneumonia in Henan. Zhonghua Jie He He Hu Xi Za Zhi. 2020;43(4):32731. https://doi.org/10.3760/cma.j.cn112147-20200222-00148 PMid:32118390

36. Wang D, Hu B, Hu C. Clinical characteristics of 138 hospitalized patients with 2019 novel Coronavirus-infected pneumonia in Wuhan, China. JAMA. 2020;323(11):1061-9. https://doi. org/10.1001/jama.2020.1585

PMid:32031570

37. Huang C, Wang Y, Li XL, Ren L, Zhao J, Hu Y. Clinical features of patients infected with 2019 novel Coronavirus in Wuhan, China. Lancet. 2020;395(15):497-506. https://doi.org/10.1016/ S0140-6736(20)30183-5

PMid:31986264

38. Yang $H$, Yuan $X$, Zhijie L, Ling $Y$, Jing $W$. The clinical implication of dynamic hematological parameters in COVID-19: A retrospective study in Chongqing, China. Int J Gen Med. 2021;14:4073-80. https://doi.org/10.2147/IJGM.S321292 PMid:34354369

39. Lanini S, Montaldo C, Nicastri E, Vairo F, Agrati D. COVID-19 disease-temporal analyses of complete blood count parameters over course of illness, and relationship to patient demographics and management outcomes in survivors and non-survivors: A longitudinal descriptive cohort study. PLoS One. 2020;15(12):e0244129. https://doi.org/10.1371/journal. pone.0244129

PMid:33370366

40. Shi H, Han X, Jiang N, Cao Y, Alwalid O, Gu J. Radiological findings from 81 patients with COVID-19 pneumonia in Wuhan, China: A descriptive study. Lancet Infect Dis. 2020;20(4):42534. https://doi.org/10.1016/S1473-3099(20)30086-4 PMid:32105637

41. Ma $Y, X u Q$, Wang $F$, Ma X, Wang $X$. Characteristics of asymptomatic patients with SARS-CoV-2 infection in Jinan, China. Microbes Infect. 2020;22(4-5):212-7. https://doi. org/10.1016/j.micinf.2020.04.011

PMid:32387682

42. Monji A, Kato T, Kanba S. Cytokines and schizophrenia: Microglia hypothesis of schizophrenia. Psychiatry Clin Neurosci. 2009;63(3):257-65. https://doi. org/10.1111/j.1440-1819.2009.01945.x

PMid:19579286

43. Naudin J, Capo C, Giusano B, Mege J, Azorin J. A diferential role for interleukin-6 and tumor necrosis factor-a in schizophrenia? Schizophr Res. 1997;26:227-33. https://doi.org/10.1016/ s0920-9964(97)00059-5

PMid:9323355
44. Kim YK, MyintAM, Verkerk R, Scharpe S, Steinbusch H. Cytokine changes and tryptophan metabolites in medication-naïve and medication-free schizophrenic patients. Neuropsychobiology. 2009;59(2):123-9. https://doi.org/10.1159/000213565 PMid:19390223

45. Luo $\mathrm{Y}, \mathrm{He} \mathrm{H}$, Zhang $\mathrm{J}, \mathrm{Ou} \mathrm{Y}$, Fan $\mathrm{N}$. Changes in serum TNF $\alpha, I L-18$, and IL-6 concentrations in patients with chronic schizophrenia at admission and at discharge. Compr Psychiatry. 2019;90:82-7. https://doi.org/10.1016/j.comppsych.2019.01.003 PMid:30782515

46. Mesa A, Cesar E, Martin-Montanez E, Alvarez E. Acute lung injury biomarkers in the prediction of COVID-19 severity: Total thiol, ferritin and lactate dehydrogenase. Antioxidants (Basel). 2021;10(8):1221. https://doi.org/10.3390/antiox10081221 PMid:34439469

47. Hasbi M, Loebis B, Camelia V. Perbedaan Kadar Tumor Necrosis Factor-Alpha dan Kadar Interleukin-2 Pada Orang Dengan Skizofrenia Yang Mendapat Risperidon Pada Fase Akut Pengobatan di Rumah Sakit Jiwa Prof.dr.M.Ildrem Medan. Indonesia: North Sumatra University; 2020.

48. Muric N, Arsenijevic N, Borovcanin M. Chlorpromazine as a potential antipsychotic choice in COVID-19 treatment. Front Psychiatry. 2020;11:612347. https://doi.org/10.3389/ fpsyt.2020.612347

PMid:33424669

49. Tsuneizumi T, Babb S, Cohen B. Drug distribution between blood and brainas a determinant of antipsychotic drug effects. Biol Psychiatry. 1992;32(9):817-24. https://doi. org/10.1016/0006-3223(92)90085-e

PMid:1360262

50. Procyshyn R, Bezchlibnyk-Butler KZ. In: Jeffries J, editor Clinical Handbook of Psychotropic Drugs. $21^{\text {st }}$ ed. Gottingen: Hogrefe Publishing; 2015.

51. Echeverría-Esnal D, Martin-Ontiyuelo C, Navarrete-Rouco M, Cusco M, Ferrandez O. Azithromycin in the treatment of COVID19: A review. Expert Rev Anti Infect Ther. 2021;19(2):147-63. https://doi.org/10.1080/14787210.2020.1813024 PMid:32853038

52. Lee N, Wong C, Chan M. Anti-inflammatory effects of adjunctive macrolide treatment in adults hospitalized with influenza: A randomized controlled trial. Antiviral Res. 2017;144:48-56. https://doi.org/10.1016/j.antiviral.2017.05.008 PMid:28535933

53. Arshad S, Kilgore P, Chaudhry Z. Treatment with hydroxychloroquine, azithromycin, and combination in patients hospitalized with COVID-19. Int J Infect Dis. 2020;97:396-403. https://doi.org/10.1016/j.jij.2020.06.099 PMid:32623082

54. Purwati, Miatmoko A, Nasronudin. An in vitro study of dual drug combinations of anti-viral agents, antibiotics, and/or hydroxychloroquine against the SARS-CoV-2 virus isolated from hospitalized patients in Surabaya, Indonesia. PLoS One. 2021;16(6):e0252302. https://doi.org/10.1371/journal. pone.0252302

PMid:34143818

55. Meyerowitz E, Vannier A, Friesen M, Schoenfeld, Gelfand J, Callahan MV. Rethinking the role of hydroxychloroquine in the treatment of COVID-19. FASEB J. 2020;34(5):6027-37. https:// doi.org/10.1096/fj.202000919

PMid:32350928

56. Meng $X Y$, Zhang $H X$, Mezei M, Cui M. A powerful approach for structure-based drug discovery. Curr Comput Aided Drug Des. 2011;7(2):146-57. https://doi. org/10.2174/157340911795677602

PMid:21534921 